\title{
Accounting Measurement Revolution and Market Value
}

\author{
Mohammad Aladwan \\ ${ }^{1}$ Accounting Department, School of Management and Finance, TheUniversity of Jordan, Jordan \\ Correspondence: Mohammad Aladwan, Accounting Department, School of Business, The University of Jordan, \\ Aqaba Branch, Jordan. E-mail: msm_adwan@ju.edu.jo
}

Received: March 28, 2018 Accepted: September 20, 2018 Online Published: October 29, 2018

doi:10.5539/mas.v12n11p279

URL: https://doi.org/10.5539/mas.v12n11p279

\begin{abstract}
The study is aims to examine whether the adoption of accounting measurement of AIS/IFRS standards has resulted in more relevant financial information for decision making or not. This study examines the use of fair value measurement on value of financial instruments to capture if there is any effect on the market value of financial companies. Ohlson (1995) framework has been employed to investigate this relationship. The Jordanian financial sector was the sample for the study during the years from 2012 to 2016. Our study findings, based on the results of correlation and multiple regression analysis showed that, market value of Jordanian financial companies is significantly positively related to financial instruments measured by fair values. The final result assured that; the new accounting measurements methods such as fair values are value relevant for Jordanian financial companiesduring all period of the study.
\end{abstract}

Keywords: IAS 39, IFRS 9, IFRS 13, market value, Jordan, financial sector

\section{Introduction}

The contribution of Ball and Brown study in 1968 was the starting point for almost all research concerning the relevant values of accounting information. Their study assured the relationship between accounting information such as earnings, cash flows, and book values of equity and market values such as share prices and income. Developing countries such as Jordan is similar to more developed countries started to adapt its accounting systems with the new approaches of accounting measurements such as fair value (FV) whom considered more relevant accounting measurement than historical cost, based on the fact that fair value reflects the current market prices and conditions. However, developing countries are also accused by the lack of necessary efficient market that is a vital requirement for the application of such measurement (Tan et al., 2015). Hence, it is still questionable whether fair value measurement could produce more relevant information than that of historical cost in these developed countries? And whether the new accounting standards in general can or should be adopted in such countries.

Measurement of assets using fair value in developing countries was regarded irrelevant for several reasons such as, the lack of active markets to assets and liabilities measured at fair value, because measurement in such markets makes fair values estimations based on subjective management methods; this consequently produce irrelevant and unreliable information for decision making. Another problem associated with the use of fair value in developing countries arise from the high costs associated with such values especially for medium and small size entities; therefore it is expected that such obtained values to be unbeneficial and contradicts with the concept of information cost/ benefit value for producing information. Another problem is also related for this measurement arise when considerable amount of income that recognized under such fair values measurements is capable to distort the real income due to the inclusion of unrealized gains or losses in financial statements. These reported figures create greater volatility in income and share prices (Barth, 2006).

For many decades developed countries as mentioned were accused by the lack of the necessary requirements for efficient market which reflects actual values; hence, it is advisable to apply fair values measurement in such markets. To stand on the reality of such accusation most of developed and emerged markets started to investigate whether they are fit for such measurements or not. Some researchers argued that, it is too early to give prior judgments on developing countries for fair value adoption due to their doubts that if this convergence will make a difference at all in benefiting decision makers (Olesen \& Cheng, 2011; Masa'deh et al., 2015;Obeidat et al., 2013; Tarhini et al., 2015). Other researchers found that market in general affected by many factors such as, 
culture, economic and legal factors and these factors are different across the world; therefore, incentives to produce reliable information might also differ according to these factors (Barlev \& Haddad, 2007). Research about fair value usefulness as accounting measure generally was conducted in many advanced countries; however, extending such research about fair value in developing countries can increase and contribute for the generalizability use of fair value and moreover results from such research is so helpful to increase the harmonization of International Financial Reporting Standards (IFRS) internationally.

In comparison of recent accounting measures such as fair value with traditional measures like historical cost; fair value was superior to historical cost due to its deficiency in reflecting current values of assets or liabilities especially for financial instruments. For such reason, it became highly essential to find other measurement technique that is both reliable and relevant to reflect current values of assets and liabilities. Several researchers supported the use of fair value as more suitable measurement on the ground that this method is capable provides more useful information to users than traditional measurement methods. They argued that, fair value approach has more incremental effect on market values than historical cost especially for stock price values; the explanatory power of fair value was found to more significantly correlate with stock prices than historical cost (Barth et al., 2008; Cohen et al., 2015).

The results of fair value measurement in different countries with deferent firm's conditions, culture, competitiveness level and economic structure is considerably different across countries (Vogiazas and Alexiou, 2015; Azamand Raza, 2018). Therefore examining fair value in different settings will contribute in more generalizability for the application of fair value. According to Deegan \& Unerman (2006), conducting several researches in different environments can increase the generalizability of the theory in question. Based on previous introduction, this study seeks to insure that; if the use of fair value measurement in a small developed country such as Jordan with newly emerged market is relevant or not. The study also is expected to extend the accounting literature for bringing more valuable insights for both academic researchers and accounting decision makers about fair value.

The rest of the paper is organised as follows. Section 2 presents a review of related theoretical and empirical literature, Section 3 presents data and methodology, Section 4 presents the findings, and the last section concludes.

\section{Review of Related Literature}

\subsection{Fair Value and Relevance Issue}

According to IFRS 13 fair value is defined as: "the price that would be obtained when selling an asset or paid for a liability in an orderly transaction between market participants at a measurement date"; the meaning of fair value include both of entry price and exit price (IFRS 13, 2012). With reference to according to accounting conceptual framework; an accounting measurement should be used only if it is reflects the best relevant and reliable value. The accounting standards assured that accounting number must have the ability to predict future, confirm past on timely basis (Francis \& Schipper, 1999). Moreover, an accounting number is relevant if an association is witnessed between market values and this number (Barth, 2000). Therefore, relevancy and reliability that characterize the financial information are regarded as the two accounting qualities that taken in to consideration when selecting evaluating different accounting measurement methods (Barth et al., 2001).

In accounting literature a lot of debate arises with or against the use of fair value as an accounting measurement; supporters of fair value pointed out that, fair value is more relevant for decision than historical cost based on the fact that its reflects current market values. Hence, historical cost should have less attention when we seeking for relevant and up to date values. Supports also criticized historical cost practically at inflation periods because historical cost is very weak to reflect any increase or decrease in market prices (Deegan \& Unerman, 2006). Another argument against historical cost that is; the accounting numbers produced lacks comparability if compared to fair value numbers (Riahi Belkaoui, 2004).

Although there was an agreement on the fact that fair value is more relevant than historical cost, opponent of fair value argued that in some cases fair value is less reliable than historical cost especially if efficient market prices are absent (Alkhadash \& Abdullatif, 2009; Carroll et al., 2003; Song, 2015). Nevertheless, fair value also was supported as an exit price based on the ground that it represents current value and up-to-date numbers that reflect true the economic substance (Penman, 2007). Another argument that supports fair value is that, current accounting values can harmonize the accounting practices worldwide through achieving more comparability in accounting numbers (Barlev \& Haddad, 2007).

Despite of all fair value benefits conservative accounting scholars oppose this measurement method claiming 
that fair value measures distorts income through the inclusion of unrealized gains and losses. Moreover; they claimed that fair value is less reliable than traditional measures. Opponents also argued that numbers of fair values are costly to prepare, and gives manager's the chance for discretion and moral hazard (Evans, 2003). Fair value also was criticized by its tendency to cause ambiguous volatility in income and thus damaging the reliability of accounting numbers (Penman, 2007; Joshi etal., 2016; Sodan, 2015). Some scholars showed concerns about irrelevance of fair value due to the incompetency of exit prices to faithfully represent some assets such as work in process, inventory or unique assets (Benston, 2008). Another concern arises with fair value use is its failure to estimate reasonable future cash flows due to the subjectivity of estimations (Ronen, 2008). In Europe; the European Central Bank report (2004) revealed some concerns from the potential wider use of fair values which might result in suspicious increase in the volatility of banks' balance sheets and hence reducing their ability for these banks to react with adverse shocks. This volatility concerns were arising from the fear of artificial fair values numbers.

In efficient market theory, market prices that are obtained from weak financial markets are questioned in terms of reliability because such markets are incapable to capture real prices (American Bankers Association, 2008). Moreover, efficient market theory assumes that fair value can work well only, if efficient market conditions are available such as liquidity and stability. The financial crises in 2009 bring to the surface many questions concerning the use of fair value, many doubts were raised about fair value numbers and their role in the crises. After the crises fair value was accused that it was the main cause for bankruptcy of many worldwide financial institution. Proponents of fair value defended for this accusation claiming that fair value always acts as a messenger that carries the values of assets and liabilities and therefore it is innocent from this accusation. The defenders also pointed out that, fair value works as a thermometer, it only mirrors reality, and it does not create it; therefore quitting fair value and returning back to historical cost will deepen the wound; and consequently this absence of fair value might make the market loss any early warnings for such problems (Laux \& Leuz, 2010; Li \& Luo, 2016).

\subsection{Measurement of Financial Instruments}

The measurement of financial instruments is regarded as one of most complicated issues in accounting standards. According to the substituted International Accounting Standard 39 (IAS 39) financial instruments are classified to four categories; firstly financial assets or liabilities at fair value profit or loss; secondly Held-to-maturity investments; thirdly Loans and receivables; and finally available-for-sale instruments. The new enacted and applied IFRS 9 that replaced IAS 39 starting 2013 revised the previous IAS 39 four classifications for only two types; financial instruments at amortized cost and financial instruments at fair value (IASB, 2009). The new applied IFRS 9 standard provided more guidance for measurement of financial instruments; the guidelines worked as a base for directing accountants and management to apply the most reliable and relevant type of accounting measurement. Although Fair value has become the preferred option for many users of accounting information; the standards prevented fair value from being applied in some cases when historical cost is regarded as the best measurement.

Another newly issued IFRS standard that guides the measurement of fair value is IFRS 13; this standard classified fair value measures to three levels. The first level is the most reliable to measure fair value; this level is applied when identical prices for assets and liabilities are available in market. Level two is less reliable than level one, fair value is determined for assets and liabilities based on the value of other similar prices of assets and liabilities in market. The third level is considered the least reliable level for estimate fair value; this level depends on management estimation for the market value of assets and liabilities (IFRS 13).

\subsection{Empirical Research}

Many of previous empirical literature was conducted on the issue of fair value relevance; this research has a great focus on the effects of fair value measures on company's income, stock prices, cash flows and market values. These studies discussed and reviewed the benefits, pitfalls and the consequences that are expected from such method application.

Barth (1994) study was regarded from the first studies that investigated the use of fair value. She examined how fair value measures of financial instruments are reflected in share prices in comparison in comparison to those values based on historical cost. The study results showed that, fair value measures of financial instruments appeared to have more significant explanatory power than those of cost measures. The results also revealed that, fair value measures have less measurement error than historical costs measures. The results confirmed that, fair values of securities gains or losses have no significant incremental explanatory power as the researcher expected. Similar results was also found by Nelson (1996) after assuring the previous results found by Barth (1994) when 
evaluating the correlation between market value of common equity of banks with fair value estimates. His results suggested that fair values of investment securities have more incremental explanatory power relative to book value and exhibit reliable evidence of significant incremental explanatory power in the fair value estimates for such type of financial instruments.

In according literature, any difference in amount between fair value and historical cost numbers is regarded as holing gains or losses; these holding gains or losses are computed by subtracting book value from market value. Some researchers pointed out that the recognition of holding gains or losses proved to have influence on the company value. For example; Simko (1999) investigated the net cumulative effect of holding gains for financial assets, financial liabilities, and derivative contracts for nonfinancial firms. After employing Ohlson model (1995) to examine the market value of equity relation with three variables: holding gains of financial assets, financial liabilities, and derivative contracts. His results showed only fair value of holding gains for financial liabilities is correlated to market value. His final results concluded that, the low explanatory power for some assets and liabilities is attributed to accounting rules that prevent the recognition of gains or losses for such assets and liabilities.

Previous literature also focused on the relationship between fair value and earning arises from the realization of abnormal returns. Several researchers proved that market value is fluctuated by the amount comprehensive income results from fair value revaluation (Kanagaretnam et al., 2009; Brickner et al., 2007; Sun, 2014; Strouhal, 2015). The same results also was achieved by Paik (2009) when he find association between changes of revaluation reserves and stock prices for 15 European countries for the year 2005. Likewise, in Europe particularly France, Arouria et al (2012) after extending Ohlson (1995) model for more general context in which different income volatility is captured through its relation with stock returns and market prices. The study main findings confirmed Ohlson (1995)'s model in that the fundamentals of fair value are relevant in explaining changes in stock prices.

The issue of faithfulness of fair value information continued to be examined by scholars through its relation with various accounting results. Dimos (2011) after questioning the usefulness of fair value use in valuation of European banks; he showed that fair value results for loans, advances, derivatives and other debt are extremely value relevant. This result assured the acceptable use of fair value estimates; the findings also approved that the cost for equity capital was decreased post the use of IFRS fair value measures.

Other than research conducted in USA and more developed countries fair value has also gained the considerable attention by many countries. Hassan and Saleh (2010) investigated the use of fair value for financial instruments disclosures in Malaysia. Their results suggested that, the absence of such measurement in market is too risky for investor's activities. The association between disclosures of fair value and market price found relevant and fair value measurement proved positive consequences on reflecting actual market value. In Middle East countries many of conducted research was also found about fair value measurement; several studies investigated such accounting measurement method and its relevance for serving and improving decision making process. El-Shamy and Kayed (2005) examined the relationship between market prices and fair value for Kuwaiti firms; based on Ohlson (1995) framework the results of the study asserted that, the incremental information content of earnings using fair value found higher than that of book values. In the same stream, Al-Barrak (2011) confirmed similar results and found a great association existed between current market values and future cash flow. Moreover, his results also showed that, earnings based on fair values provide more incremental explanatory power beyond that provided by current cash flows. In United Arab Emirates Khanagha (2011) also confirmed gulf region results about fair value. However, his results likewise suggest that, the incremental information content of cash flows' was increased post-IFRS newly emerged measurement methods such as fair value.

As for Jordanian market several studies also conducted regarding fair value measurement. Almost all of these studies encouraged this measurement use (Koury, 2000; Siam \& Abdullatif, 2011; Alkhadash \& Abdullatif, 2009; Al-saeed, 2008; Al-Yaseen and Alkhadash, 2011; Alfatih et al., 2015). Many of these studies privileged and preferred fair value as a measurement for assets such as financial instruments rather than historical cost. From the important Jordanian a study conducted by Alkhadash (2012) that examined the effect of implementing fair value accounting under IAS 40 for Jordanian firms. His study revealed that, market value of share prices was generally associated with fair value disclosures. Furthermore, the study showed that, the inclusion of unrealized gains and losses affect the net income. The net income and book values jointly and individually are found positively and significantly related to stock prices; hence, fair value disclosures are proved to be relevant. Another respected Jordanian study related to the subject, is the study of Alkhadash \& Abdullatif (2009) whom investigated economic consequences of fair value on Jordanian commercial and investment banks for the period 
from 2002 to 2006. The findings of their study also confirmed the importance of fair value measures and revealed its significance association with market values of stocks; the final conclusion of the study supported the use of value in evaluating financial instruments.

We can summarize our previously reviewed literature about fair value that, almost in all countries research results have found that fair value accounting is value relevant and affects share prices, earnings, market values and future performance. On the other hand, these studies have also reported some concerns about the use of fair value accounting especially if the suitable market conditions for fair value use are absent.

\section{Data and Methodology}

\subsection{Data}

The community of the study includes the financial companies listed in Amman Stock Exchange (ASE) for the years (2012-2016) including banks, insurance, real state and diversified financial services. Companies that applied fair value revaluations and those that did not. The total number of companies was 108 with 540 observations. Financial data was obtained from the Jordanian companies' guide 2017 and from the yearly annual reports. The related literature for the study was obtained from journal papers, conferences, thesis, accounting text books and any other necessary sources.

\subsection{Methodology}

According to accounting conceptual framework any financial information is relevant if it is provide reasonable, faithful and current values for decision maker. Therefore, relevant measurement methods have to reflect any changes in current value of assets and liabilities with acceptable transparency.

As previously mentioned in literature the reported unrealized gains and losses resulted from fair values revaluations are showed in income or in owners' equity for current period; and when these gains or losses are disclosed to the market they effects the market value for companies (Barth, 2000; Alkhadash, 2012). One of the most popular widely used models for market valuation is Ohlson model (1995); it is known as the balance sheet valuation model. This model is derived from the popular accounting equation; according to this model, market value of a stock equity equals the sum of the book values of the firm's assets minus liabilities. The model can be expressed as follows:

$$
\text { Market Value of Equity = Book value of assets }- \text { Book value of liabilities }+E(1)
$$

To isolate financial instruments from other types of assets the model is decomposed as follows:

$$
\text { Market Value of Equity = Book value financial instruments }+ \text { Book value other assets }- \text { Book }
$$

$$
\text { Value other liabilities }+ \text { Fair value financial instruments }+E
$$

Therefore, the empirical model that will be employed in our study is:

$$
P_{i t}=\alpha_{o}+\alpha_{1} F V F I_{i t}+\alpha 2 B V F I_{i t}+\alpha_{3} B V O A_{i t}-\alpha 4 B V O L_{i t}+E_{t i}(3)
$$

Where;

$P_{i t}:$ company market value represented by stock price at the end of year $\mathrm{t}$.

$F V F I_{i t}$ : company i fair value of financial instruments at the end of year $\mathrm{t}$.

$B V F I_{i t}$ : company i Book value of financial instruments at the end of year t. $B V F I_{i t}$ is measured as fair value of financial instruments (less or plus) revaluations of financial instruments.

$B V O A_{i t}$ : company i book value of other assets at the end of year t. $B V O A_{i t}$ is measured as non-financial assets less financial instruments.

$B V O L_{i t}$ : company I book value of other liabilities at the end of year t. $B V O L_{i t}$ is measured asnon-financial liabilities less financial liabilities.

\section{The Findings}

\subsection{Summary Statistics}

Table 1 shows the descriptive statistics for the dependent and independent variables of the study that discussed in equation (3). As appear from the table results, the mean value of $\mathrm{P}$ (mean: 1.965; median: 1.328) is close to its median which can be explained to mean that; share prices of financial instruments volatile in market and reasonably reflects participant's evaluations of market share prices. The book value of financial instruments and fair value of financial instruments of Jordanian financial sector are relatively close to each other's (11409 and 11371) the change in fair value from book value is approximately about 0.003 this can be explained that 
Jordanian investors are very cautious when evaluating market values. Other variables such as BVOA, BVOL, have mean values greater than their medians, with very high standard deviation; this can be referred to the difference in size between banks and other types of financial companies. The descriptive results of the model variables show that the mean of FVFI is greater than the mean of BVFI by a net change of 39 million. This result indicates that Jordanian financial company's reports include unrealized gains and losses because of fair value use; As we mentioned in our model FVFI equals BVFI plus (less) of fair value revaluations. In the next tests of the study we will examine which of BVFI or FVFI have more ability to capture the market value for Jordanian financial companies.

Table 1. Descriptive Statistics of the study Variables

\begin{tabular}{lccccc}
\hline & $\mathrm{P}$ & FVFI $_{(000,000)}$ & BVOA $_{(000,000)}$ & BVOL $_{(000,000)}$ & BVFI $_{(000,000)}$ \\
\hline Mean & 1.965 & 11409 & 49369 & 2616 & 11371 \\
Median & 1.328 & 5825 & 22316 & 812 & 5886 \\
Std. Deviation & 1.777 & 19282 & 88154 & 5469 & 19034 \\
Minimum & 0.134 & 57 & -1347 & 237 & 95 \\
Maximum & 9.459 & 88921 & 385161 & 36802 & 88177 \\
\hline
\end{tabular}

$* \mathrm{~N}=540$

\subsection{Analysis and Discussion}

Before conducting the correlation test, normality of the study sample was tested and the results showed that the sample was normally distributed. Therefore, Pearson Correlation was chosen to test Correlation between the model variables.

Table 2 shows the correlation matrix results between the model variables of equation (3). The results show a high correlation between book value of financial instruments BVFI and fair value of financial instruments FVFI. Therefore, Multicollinearity may exist between these two independent variables; hence, we will exclude BVFI from our equation because the focus of the study is to examine FVFI. However, before conducting the regression test Preliminary evidence obtained from correlation that is, superiority of fair value is more correlated with market value than book value as appear in the results; correlation of FVFI with share price $(0.814)$, which is higher than BVFI correlation (0.671).

Table 2. The Correlation between the Variables of the Model

\begin{tabular}{|c|c|c|c|c|c|c|}
\hline & & $P$ & $B V F I$ & $B V O A$ & $B V O L$ & $F V F I$ \\
\hline \multirow[t]{2}{*}{$P$} & Pearson Correlation & 1 & & & & \\
\hline & Sig. (2-tailed) & . & & & & \\
\hline \multirow[t]{2}{*}{$B V F I$} & Pearson Correlation & $.671(* *)$ & 1 & & & \\
\hline & Sig. (2-tailed) & .000 & . & & & \\
\hline \multirow[t]{2}{*}{$B V O A$} & Pearson Correlation & $.715(* *)$ & $.963(* *)$ & 1 & & \\
\hline & Sig. (2-tailed) & .000 & .000 & . & & \\
\hline \multirow[t]{2}{*}{$B V O L$} & Pearson Correlation & $.418(* *)$ & $.460(*)$ & $.382(* *)$ & 1 & \\
\hline & Sig. (2-tailed) & .002 & .001 & .003 & . & \\
\hline \multirow[t]{2}{*}{$F V F I$} & Pearson Correlation & $.814(* *)$ & $.957(* *)$ & $.910(* *)$ & $.371(*)$ & 1 \\
\hline & Sig. (2-tailed) & .000 & .000 & .000 & .003 & . \\
\hline
\end{tabular}

$\mathrm{N}=540$

** Correlation is significant at the 0.01 level (2-tailed).

* Correlation is significant at the 0.05 level (2-tailed). 
As we discussed earlier the Hypothesis of the study raises the issue for benefiting from fair value estimates in financial company's valuation. Given that, fair value numbers are more relevant for investment decision. The regression results of the study model equations (3) are presented in table 3 panel A. As the correlation results showed of possible Multicollinearity; the regression will be applied twice. First run when all the model variables are included in regression and in the second run when $B V F I$ is excluded from model to overcome Multicollinearity effect. The first run of regression is aimed to find which of the two correlated variables $B V F I$ or FVFI have the best coefficient, with higher $\mathrm{t}$ value, with best significance before excluding book value of financial instruments $B V F I$.

Panel A in Table 3 indicates the regression results after all independent variables of the model are included in the regression. The results showed that the book value of financial instruments $(B V F I)$ is significantly positively associated with market value (coefficient $=3.980 \& \mathrm{t}$-stat $=2.639 \& \mathrm{sig}=0.010$ ). This result proves that book value is beneficial for decision making. In the same table Panel A also show that fair value of financial instruments $(F V F I)$ is more value relevant than $(B V F I)$ and more associated with market value; the results indicated (coefficient $=4.166 \& \mathrm{t}$-stat $=2.918 \& \mathrm{sig}=0.003$ ). These results too prove the superiority of fair value over book value; in other wordsFVFI have higher explanatory power for market value $(p)$ than $B V F I$. As appear our results is consistent with the results of (Barth, 1994; Nelson, 1996; Paik, 2009; Alkhadash \& Abdullatif, 2009; Al-Barak, 2011).

As mentioned previously in the study about the Multicollinearity that existed between $B V F I$ and FVFI, and that the aim of the study to determine the more relevant independent variable that explain the changes in dependent variable. Therefore, we will exclude $B V F I$ from the model and focus only on FVFI. Although high correlation appeared between $B V F I$ and $F V F I$ in table 3, the variance inflation factor (VIF) for both $B V F I$ and $F V F I$ was $<5$. Consequently, we repeated the regression of the model as appeared in panel B to capture only the effect of $F V F I$ since it's our objective to examine. Therefore, the new equation will be:

$$
\mathrm{P}_{\text {it }}=\beta_{\mathrm{o}}+\beta_{1} \mathrm{FVFI}_{\text {it }}+\beta_{2} \mathrm{BVOA}_{\text {it }}-\beta_{3} \mathrm{BVOL}_{\text {it }}+\mathrm{E}_{\mathrm{ti}}
$$

Panel B Table 3 provide regression results of equation 3 after excluding BVFI, its evidenced from the results that FVFI being positive and significantly associated with market value with a coefficient $=7.058, \mathrm{t}$-stat $=2.924$ and $\operatorname{Sig}=0.000$. This result is also consistent with (Barth, 1994; Nelson, 2006; Alkhadash \& Abdullatif, 2009; Hassan \& Saleh, 2010).

Table 3. Regression Results for Association between Financial Instruments Fair Value and Market Value.

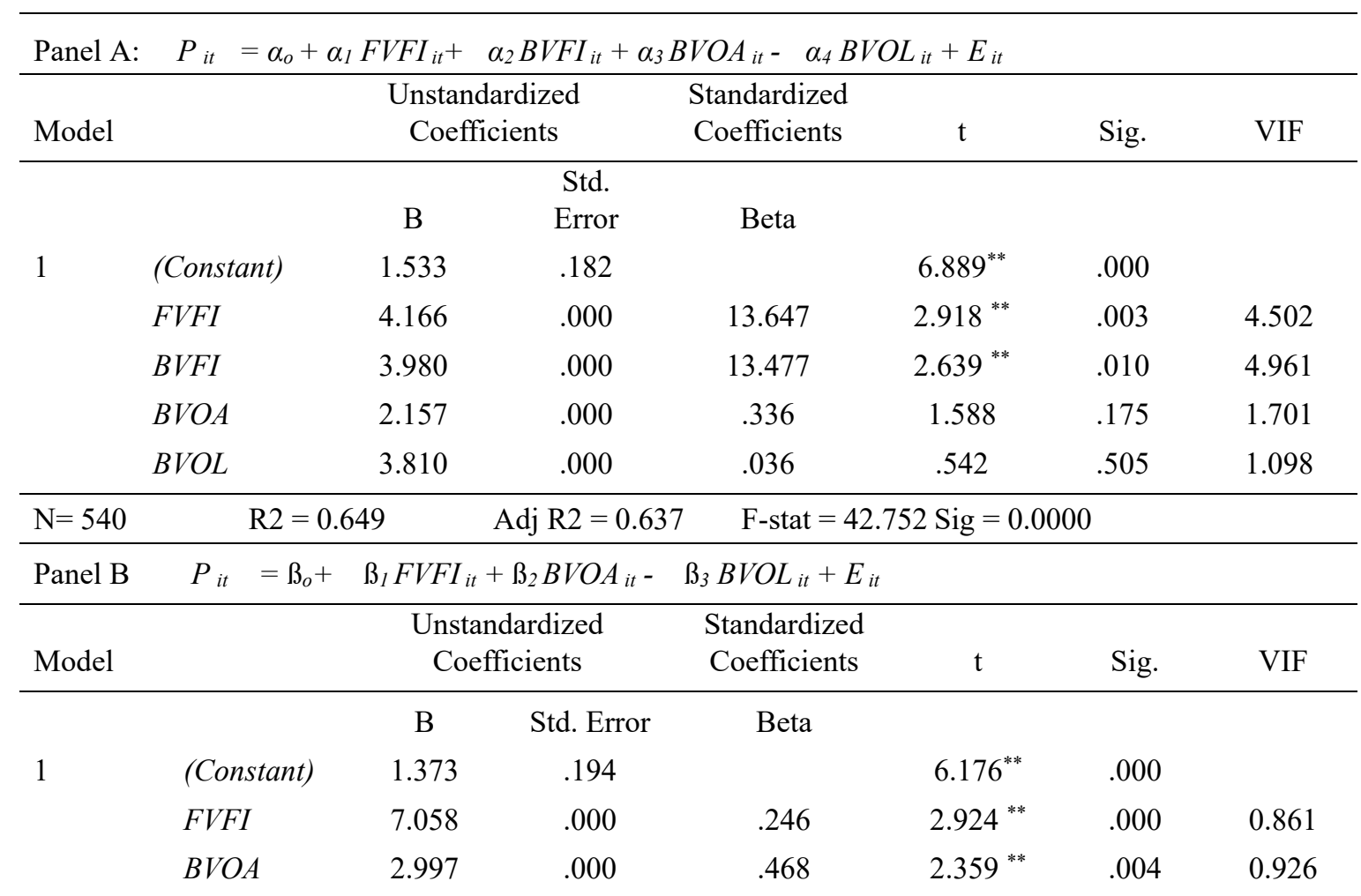




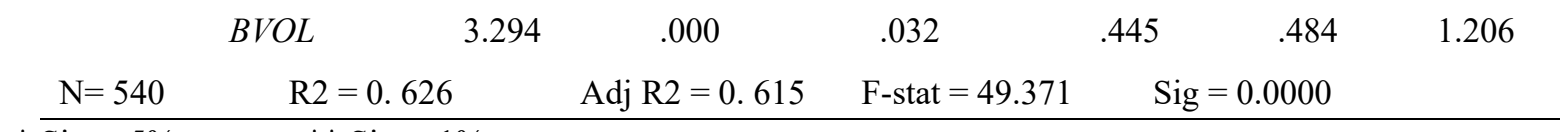

$*$ Sig at $5 \% \quad * *$ Sig at $1 \%$

However, the fair value of financial instruments, as the results show, provide more explanatory power of market value represented in share price, and its significantly positively related with market values beyond those of book values (Barth, 1994; Carroll et al., 2003; Barth et al., 2001; Nelson, 2006; Danbolt \& Rees, 2008; Kanagaretnam et al., 2009). Generally, our previously results is consistent with almost all the findings of global, regional and local results concerning the issue of the study. Consequently, fair value measurement was found relevant to reflect the market value of financial instruments for Jordanian financial companies.

\section{Conclusions}

This study was motivated by the shortage of empirical studies in emerged markets (Jordan an example) on how market value is associated with the type of accounting measurement. Many argued that fair value model is considered superior to other types of accounting measurements such as historical cost. Fair value is supported on the ground that it's more helpful in presenting values of assets and liabilities and provide more faithful picture about the company's financial values. In the contrary, opponents of fair value model argued that, uncertainty that might be associated with the use of fair value might cause unsatisfied volatility in the accounting information numbers. Moreover, they argued that the use can distort financial statements with subjective numbers and thus mislead investors and creditors. Therefore, the primary objective of the study was to investigate whether the adoption of such measurement (FV) is useful for financial reporting environment or not and can support the ongoing use of fair value.

Our general findings of the study after examining the association between fair value measurement and market value for financial companies provided conclusive evidence about the significant relationship that existed between fair value measurements and market value. Hence, fair value use in Jordan is relevant similar to other countries worldwide. These results also can be added to the other international and local literature for confirming the importance of fair value application. Our overall results assured that fair value measurements is applicable, relevant, reliable and serve the primary objective of accounting information for helping the different users in their decision.

\section{References}

Al-Barrak, T. (2011). Value relevance and predictive ability of financial statement information: The case of Saudia Arabia. Unpublished Doctoral Thesis, University of Portsmouth.

Alfatih, A., Abdalrahim, E., \& Elzain, S. (2015). The impact of the application of fair value accounting on the quality of accounting information. International Journal of Academic Research in Accounting, Finance and Management Sciences, 5(1), 148-160.

Alkhadash, H. (2012). The value relevance of fair value accounting of investment properties in the Jordanian shareholding companies. Int. J. Accounting, Auditing and Performance Evaluation, 8(4), 373-393.

Alkhadash, H., \& Abdullatif, M. (2009). Consequences of fair value accounting for financial instruments in the developing countries: The case of banking sector in Jordan. Jordan Journal of Business Administration, 5(4), 533-551.

Al-Saeed, M. (2008). The impact of disclosure, applying the concept of fair value according to changes in the international financial reporting standards on financial reporting of insurance companies in Jordan. Unpublished Doctoral Thesis, Amman Arab University, Amman, Jordan.

Al-Yaseen, B., \& AlKhadash, H. (2011). Risk relevance of fair value income measures under IAS 39 and IAS 40. Journal of Accounting in Emerging Economies, 1(1), 9-32.

American Bankers Association (2008). Letter to SEC on fair value and other accounting standards. Washington: September 23, 2008.

Amman Stock Exchange. http://www.ase.com.jo. 2011-2016. Companies Guide \& Annual Reports.

Arouria, M., Bellalahb, M., Hamidac, N., \& Nguyen, D. (2012). Relevance of fair value accounting for financial instruments. International Journal of Business, 17(2), 209-220.

Azam, M., \& Raza, A. (2018). Financial sector development and income inequality in ASEAN-5 countries: Does 
financial Kuznets curve exists? Global Business and Economics Review, 20(1), 88-114.

Ball, R., \& Brown, P. (1968). An empirical evaluation of accounting income numbers. Journal of Accounting Research, 6(2), 159-178.

Barlev, B., \& Haddad, J. (2007). Harmonization, comparability, and fair value accounting. Journal of Accounting, Auditing and Finance, 22(3), 493-509.

Barth, M. E, Landsman, W., \& Lang, M. (2008). International accounting standards and accounting quality. Journal of Accounting Research, 46(3), 467-498.

Barth, M. E. (1994). Fair value accounting: Evidence from investment securities and the market valuation of banks. The Accounting Review, 69(1), 1-25.

Barth, M. E. (2000). Valuation-based accounting research: Implications for financial reporting opportunities for future research. Accounting and Finance, 40, 7-31.

Barth, M. E. (2006). Including estimates of the future in today's financial statements. Accounting Horizons, 20(3), 271-285.

Barth, M. E., Beaver, W. H., \& Landsman, W. R. (2001). The relevance and value relevance literature for financial accounting standard setting: Another view. Journal of Accounting and Economics, 31, 77-104.

Barth, M. E., Landsman, W., \& Wahlen, J. (1995). Fair value accounting: Effects on banks' earnings volatility regulatory capital and value of contractual cash flows. Journal of Banking \& Finance, 19, 577-605.

Benston, G. (2008). The shortcomings of fair-value accounting described in SFAS 157.Journal of Accounting and Public Policy, 27(2), 101-114.

Brickner, D., Brown, C., \& Myring, M. (2007). Using fundamental analysis of financial information to explain unexpected market behavior. Global Business and Economics Review, 9(4), 366-380.

Carroll, T., Linsmeier, T. J., \& Petroni, K. R. (2003). The reliability of fair value versus historical cost information: Evidence from closed-end mutual funds. Journal of Accounting, Auditing and Finance, 18(4), $1-23$.

Cohen, S., Karatzimas, S., \& Venieris, G. (2015). The informative role of accounting standards in privatizing state-owned property: Comparing Greek governmental accounting standards and IPSAS. Global Business and Economics Review, 17(1), 51-62.

Danbolt, J., \& Rees, W. (2008). An experiment in fair value accounting: UK investment vehicles. European Accounting Review, 17(2), 271-303.

Deegan, C., \& Unerman, J. (2006). Financial accounting theory, European edition, McGraw-Hill Companies, Inc., London, UK.

Dimos, A. (2011). IFRS and European commercial banks: Value relevance and economic consequences. Unpublished Doctoral Thesis, University of Aberdeen.

El-Shamy, M., \& Kayed, M. (2005). The value-relevance of earnings and book value in equity valuation: An international perspective-The case of Kuwait. International Journal of Commerce and Management, 15(1), 68-79.

European Central Bank. (2004). Fair value accounting and financial stability, Occasional Paper Series No. 13.

Evans, T. (2003). Accounting theory, contemporary accounting issues, Thomson Learning, South-Western, South-Western, Cincinnati, USA.

Francis, J., \& Schipper, K. (1999). Have financial statements lost their relevance? Journal of Accounting Research, 37, 319-352.

Gebhardt, G., Reichardt, R., \& Wittenbrink, C. (2004). Accounting for financial instruments in the banking industry: Conclusions from a simulation model. European Accounting Review, 13(2), 341-371.

Hassan, M., \& Saleh, N. (2010). The value relevance of financial instruments disclosure in Malaysian firms listed in the main board. Int. Journal of Economics and Management, 4(2), 243-270.

IASB (2003). International accounting standard 32: Financial instruments: disclosure and presentation.

London: International Accounting Standards Board.

IASB (2003). International accounting standard 39: Financial instruments: Recognition and measurement. 
London: International Accounting Standards Board.

IASB (2009). International financial reporting standard 9: Financial instruments. London: International Accounting Standards Board.

IASB (2010). The conceptual framework for financial reporting. International Accounting Standards Committee: London, UK.

IFRS (2012). IFRS 13, measuring the fair value of unquoted equity instruments within the scope of IFRS 9 financial instruments. http://www.IFRS.org.

Joshi, P., Ling, L., Yin, L., \& Deshmukh, A. (2016). Disclosure choices, corporate characteristics and compliance with IFRS practice statement management commentary: An empirical study of Malaysian listed companies. Global Business and Economics Review, 18(6), 679-703.

Kanagaretnam, K., Mathieu, R., \& Shehata, M. (2009). Usefulness of comprehensive income reporting in Canada. Journal Accountability Public Policy, 28, 349-365.

Khanagha, J. (2011). Value relevance of accounting information in the United Arab Emirates. International Journal of Economics and Financial Issues, 1(2), 33-45.

Koury, S. (2000). Financial instruments accounting. Journal of Jordanian Banks, 20, 36-41.

Laux, C., \& Leuz, C. (2010). Did fair-value accounting contribute to the financial crisis? Journal of Economic Perspectives, 24, 93-118.

Li, X., \& Luo, T. (2016). The impact of fair value accounting on corporate disclosure. China Accounting and Finance Review, 18(4), 36-56.

Masa'deh, R., Tayeh, M., Al-Jarrah, I., \& Tarhini, A. (2015). Accounting vs. market-based measures of firm performance related to information technology investments. International Review of Social Sciences and Humanities, 9(1), 129-145.

Nelson, K. (1996). Fair value accounting for commercial banks: An empirical analysis of SFAS No. 107. The Accounting Review, 71(2), 161-182.

Obeidat, B., El-Rimawi, S., Maqableh, M., \& Al-Jarrah, I. (2013). Evaluating the profitability of the Islamic banks in Jordan. European Journal of Economics, Finance and Administrative Sciences, 56, 27-36.

Ohlson, J. A. (1995). Earnings, book values and dividends in equity valuation. Contemporary Accounting Research, 11, 661-687.

Olesen, K., \& Cheng, F. (2011). Convergence of accounting standards does not always lead to convergence of accounting practices: The case of China. Asian Journal of Business and Accounting, 4(1), 23-58.

Ozcelebi, O. (2014). Possible effects of the stock market movements on interest rates, output and inflation: Empirical evidence from the emerging markets of Europe. Global Business and Economics Review, $16(2), 179-201$.

Paik, G. (2009). The value relevance of fixed asset revaluation reserves in international accounting. International Management Review, 5, 1-9.

Penman, S. (2007). Financial reporting quality: Is fair value a plus or a minus? Accounting and business research, special issue. International Accounting Policy Forum, 37(1), 33-44.

Riahi-Belkaoui, A. (2004). Accounting theory, 5thEdition, Cengage Learning EMEA, International Thomson Publishing Co., UK.

Ronen, J. (2008). To fair value or not to fair value: A broader perspective. ABACUS, 44(2), 181-208.

Siam, W., \& Abdullatif, M. (2011). Fair value accounting usefulness and imp limitation obstacles: Views from bankers in Jordan. Journal of Accounting and Economics, 22, 79-117.

Simko, P. J. (1999). Financial instrument fair values and nonfinancial firms. Journal of Accounting, Auditing \& Finance, 14(3), 247-274.

Sodan, S. (2015). The impact of fair value accounting on earnings quality in Eastern European countries. Procedia-Economics and Finance, 32, 1769-1786.

Song, X. (2015). Value relevance of fair values-empirical evidence of the impact of market volatility. Accounting Perspectives, 14(2), 91-116. 
Strouhal, J. (2015). Historical costs or fair value in accounting: Impact on selected financial ratios. Journal of Economics, Business and Management, 3(5), 560-564.

Sun, L. (2014). Fair value and its economic consequence on the volatility measures of earnings, stock price and government debt yield. Theoretical Economics Letters, 4, 910-915.

Tan, H., Wong, M., \& Elshareif, E. (2015). The impact of volatility shifts on market efficiency: The case of four emerging southeast Asian stock markets. Global Business and Economics Review, 17(2), 203-216.

Tarhini, A., Mgbemena, C., \& Trab, MSA. (2015). User adoption of online banking in Nigeria: A qualitative study. Journal of Internet Banking and Commerce, 20(3), 1-8.

Vogiazas, S., \& Alexiou, C. (2015). Banking performance and the business cycle: Empirical evidence from Greece. Global Business and Economics Review, 17(4), 345-359.

Wilson, A. (2001). Fair value and measurement: Where the conflicts lie. Balance Sheet, 9(4), 26-33.

\section{Copyrights}

Copyright for this article is retained by the author(s), with first publication rights granted to the journal.

This is an open-access article distributed under the terms and conditions of the Creative Commons Attribution license (http://creativecommons.org/licenses/by/4.0/). 